\title{
THE INFLUENCE OF TEAMS AND TEAM WORK ON COMPETITIVENESS OF ENTERPRISES
}

\author{
Snežana LEKIĆ ${ }^{1}$, Srđan BOGETIĆ ${ }^{2}$, Dragiša RANĐIĆ ${ }^{2}$ \\ ${ }^{1}$ Belgrade Business School, 11000 Belgrade, 73 Kraljice Marije, Republic of Serbia. Corresponding author. E-mail: \\ snezana.lekic@bbs.edu.rs \\ ${ }^{2}$ Belgrade Business School, 11000 Belgrade, 73 Kraljice Marije, Republic of Serbia.
}

Accepted 1 November, 2011

\begin{abstract}
Global markets, dynamism, high product quality requirements, shorter product life cycle are the factors that create the need for companies to be flexible, innovative, higher in production quality and quicker in reaction to customer's demands. Successful companies are those that have teams and team work in the basement of their business strategies and organizational processes. Organization complexity rise require teams as a group of people acting together in fulfillment of company's goals. There is a direct correlation between team work and business effectiveness of companies. Modern company management tries to create expert teams which are able to create new business solutions and motivate workers to work effectively and with the expected results. Paper analyses team work effectiveness and factors determining it. Basic hypothesis are proved on the small and medium companies case study.
\end{abstract}

Keywords: teams, team work, innovation, quality, team effectiveness.

\section{INTRODUCTION}

The growth of organizations and the increase of organizational structure complexity create the need for introducing teams in which people work together toward a common goal of the organization. The main reason for this is the correlation between team work and effectiveness of business organization. For these reasons managers in modern organizations are trying to make competent teams necessary for development of new business solutions, strengthening the motivation of people for achieving the results and increasing work efficiency.

\section{TEAMS AND TEAM WORK}

A team implies a group of people who influence each other in order to achieve the goals of the organization. It can be conceived as a formal group of people with a specific task whose members possess complementary skills, dedication to common goals and tasks. The most common types of teams in organizations are (Robbins and Coulter, 2005, p. 383):

- Problem solving teams. Teams that are formed with a sole purpose of studying and proposing solutions for a particular, specific problem in an organization. It is usually made of experts from one business function or department and the one where the problem arises. A typical problem solving team comprises 5 to 12 members and is created in order to discuss the ways to improve the quality in all phases of production in an organization, to make organizational processes more effective and enhance work environment.

- Self-management teams. The chief goal for making these teams is giving authority to those nearest to problems with a view to shortening the process of solving the problems and to making the solution better by using the information and knowledge on the lower hierarchy levels. Independent work teams are responsible for the completion of deal and team management. It usually entails planning and terms connected to the business, distribution of tasks to the members, controlling the work rate, making operative decisions and taking measures when problems occur.

- Interfunctional teams. These teams are formed of employees on the same hierarchy level but from different work fields and different business functions with the goal of solving common problems. These teams are used to achieve concentration of different competences necessary for solving complex problems. They have proved useful in cooperation between organizations 
dealing with high technologies and they are widespread as a way of cooperation of experts in different fields enabling them to exchange information, generate new ideas, solve complex problems and coordinate complex projects.

- Virtual teams. Teams that use modern information technologies for connecting separated members of the group for achieving the common goal. By using electronic mail, video conferences, web pages, intranet nets members of the team can be in different parts of the world and still work as a team. A serious disadvantage of this type of teams should be emphasized. It is the fact that physical distance prevents the members of the team from making social connections that are sometimes essential for the success of the team.

The following advantages and disadvantages of team work have been noticed (Zemke, 1993). Advantages of team work are: higher motivation of employees, increased productivity, greater satisfaction of employees, higher dedication to goals of organization, better communication among employees, improvement of business skills, better business flexibility, considerable decrease of costs (by eliminating the middle layer of management). Disadvantages of team work are: stress and frustration from maladjustment to team work, elimination of the middle layer of management that is a sort of recruiting center for top managers, phenomenon of group thinking that suppresses creativity, saturation with team work can lead to the drop of performances.

\section{Team building}

For building effective teams in an organization, it is necessary (Janićijević, 2008, pp. 165-167):

a) To design a team in an appropriate way - entails a number of activities from the field of organizational structuring and human resources, namely: defining the task, defining authority of the team, establishing optimal team size, defining team structure, chosing team members, training of team members.

b) To ensure the adequate context of team work - to make the adequate environment in which team members can complete their tasks and accomplish goals of the team. Several components of the context influence the performances of the team: the position of team in organizational structure, resources for team work, reward system and grading of performances.

c) To build "team players"- design of the team refers to defining team roles and chosing team members that will be suitable for team roles. Team role represents a number of typical behaviour for a specific team position. For a member of a team is said that he is a good "team player" when he successfully performs his team role at the appropriate position. There are nine roles in an efficient team (Robbins and Judge, 2010, p. 348): innovator, promoter, analyst, organizator, producer, controller, supporter, counselor and integrator.

The critical point of team work is trust and the way this trust is created. The experience with work teams shows that the trust has five dimensions: integrity implies that individuals value personal honesty and justice; competence - skills in defining problems, creating alternative solutions, evaluation of these alternatives and making right decisions, consistency - implies reliability, consistent behaviour and successful coping with all situations, loyalty - the wish to protect the honour and honesty of each member of the team and contributes to trust; and openness - manifests as a wish to share the ideas and information with other people.(Robbins and Coulter, 2005, p. 356)

\section{Phases of team development}

Every team has four phases of development (Pavlovski and Pavlović - Breneselović, 2000, pp. 24-25):

1. Creating - Future members of the team gather and concentrate on a problem that will be solved by the team. In this phase people are cautious; careful about what they say, evaluate others, consider whether they should join the team or not, evaluate their own strength and adequacy of their capabilities in comparison with others and things that will be expected of them, they gather impressions about other people, analyze the atmosphere and leader as the task that awaits them. In this phase people compare their expectations and the things that await them. The better people are informed about the atmosphere and nature of work that awaits them, the less stressful this phase will be, ensuring that people who remain are really interested in the work.

2. Waving - People start to get into interaction, exchange information, define their roles more precisely, realize their positions and ways of cooperation in a team. During this period, as previous statuses are not cancelled and majority of members are not used to cooperation on common task, there is competition, reconsidering, crticism that is not constructive yet. Mutual agreement is hard to achieve and 
individuals, giving their opinion on something, are still not ready to give it up in favour of a constructive suggestion. New roles, that individuals gained by being part of the team are still stiff, and individuals are sometimes suspicious of other roles and fight for their own instead of common status. This stage is called "waving" because in this phase the movements are back and forward, individuals observe themselves and other people in turns but not the team as a whole. Team moves like a wave toward defing its identity and this phase is less pleasant for the participants.

3. Standardization - After a certain number of completed tasks; team gets feedback information about its work; reconsiders some of existing roles; notices that some members of the team do not work well; estimate the competence of the leader; estimates what capabilities are missing in team; if the structure of the team is on shaky foundation, it faces possible build up of tensions. In this phase team finds a normal way of functioning. Procedures and basic rules of functioning are created that suit all members (from bigger, more formal: how to solve problems, how to transmit information in team; what is the quality minimum when doing business etc. to informal: who prefers which tasks in the team, who possesses which capabilities, what is to be tolerated, when making breaks and writing summaries etc.)

4. Functioning - Phase in which the team really functions: it has been tested in many situations and businesses; guarantees quality; roles in the team are structured but flexible at the same time; members are satisfied with interaction within the team. The team gains strength and seriousness in this phase, defines its profile and identity, builds its style and elegance. As the structure of the team has been already built in this phase, new members can join the team without the danger of destabilizing it. The members of the team help each other much more than they used to: they feel better, they are more relaxed, they have better knowledge of capabilities of their own and others and they are ready to experiment with some new roles and businesses. In these phase team also measures its strengths and effectiveness: it is interested in feedback about the functioning of the team that can be provided by an outside source; it is interested in exchange with other teams.

\section{Maintaining of team`s positive energy}

The team uses its basic energy on solving the existing problems and on mutual interaction. Energy is also spent on self-restoration (redifining the roles, introducing new members etc.) and growth (quantative growth or broadening of team`s functions; gaining new roles; acquiring new competences).

The team also uses energy on protection of its own interests, when its normal functioning is threatened either from outside or inside (team members are threatened, the results are underestimated, work is obstructed etc.). The spent energy should be restored, and every team works on that in several different domains:

- Work on its own creativity and acquiring new capabilities,

- Work on improving interaction and quality of communication,

- Standardization of functions that have become common practise,

- Work on self-evaluation and protection of team`s identity. (Pavlovski and Pavlović - Breneselović, 2000, pp. 26-27)

Revitalization of energy necessary for team`s functioning and becoming aware of processes within it can be achieved in a variety of ways. High quality teams are functional and flexible, open for new experience and ready to pose challenge independently, creating and estimating success of its own actions.

\section{CASE STUDY}

Team work research is a part of wider research dealing with the influence of organizational behaviour on organizational dedication, (Lekić, 2010, pp. 216-273). The goal of research is contribution to a better understanding of phenomenon of team work efficiency and factors influencing it. In this work the empahsis is put on a group of small and middle-sized enterprises (which are not separated), on the sample of 78 respondents. The research included 56\% female and $44 \%$ male respondents.

The questionnaire for team work consists of four categories of questions: synergy in team which represents the sense of belonging shared by team`s members: skills of associates describing training of team`s members, competence in doing business and flexibility within scope of work: innovations that involve finding ways for improving productivity and 
mode of work; quality that measures the level of familiarity with clients' needs and standards for following their satisfaction. The questionnaire is made according to methodology suggested by Bateman, B., Wilson C. F. and Bingham, D. (2002, pp. 215-226).

The questionnaire consists of Likert type responses scale and the responses on the scale from 1 to 5 indicate the degree of agreement or disagreement with a particlular statement: 1 . Strongly disagree; 2. Disagree; 3. Neither agree nor disagree; 4. Agree; 5. Strongly agree.
Synergy in team - is evaluated as average value of eight factors: clearly defined belonging to the team, clearly defined meaning/goal of the team, clear role of team members, efficient communication within the team, sense of value of team members, other organizational parts of company appreciate the team in which an individual works, the sense of pride for belonging to the team, every member contributes to team work to the maximum. In table 1 are given average value, standard deviation and coefficient of variation for particular factors of team synergy.

Table 1: Assessment of sinergy in team $(N=78)$

\begin{tabular}{|l|c|c|c|c|c|c|c|c|}
\hline & $\begin{array}{c}\text { Average } \\
\text { alue }\end{array}$ & $\begin{array}{c}\text { Standard } \\
\text { deviation }\end{array}$ & $\begin{array}{c}\text { Coefficient of } \\
\text { variation (\%) }\end{array}$ & 1 & 2 & 3 & 4 & 5 \\
\hline Clearly defined belonging to the team & 3.46 & 0.96 & 27.82 & 1 & 15 & 17 & 37 & 8 \\
\hline Clearly defined goal of the team & 3.50 & 1.00 & 28.66 & 2 & 13 & 17 & 36 & 10 \\
\hline Clear role of team members & 3.33 & 1.01 & 30.45 & 1 & 20 & 17 & 32 & 8 \\
\hline Efficiency of communication & 3.51 & 1.00 & 28.56 & 3 & 9 & 22 & 33 & 11 \\
\hline Sense of value of team members & 3.82 & 0.85 & 22.22 & 1 & 6 & 12 & 46 & 13 \\
\hline $\begin{array}{l}\text { Appreciation of the team by other } \\
\text { organizational parts }\end{array}$ & 3.32 & 1.03 & 30.89 & 3 & 13 & 28 & 24 & 10 \\
\hline $\begin{array}{l}\text { The sense of pride for belonging to the } \\
\text { team }\end{array}$ & 3.65 & 0.91 & 24.88 & 1 & 9 & 17 & 40 & 11 \\
\hline $\begin{array}{l}\text { Every member contributes to team work to } \\
\text { the maximum }\end{array}$ & 3.46 & 1.10 & 31.81 & 4 & 13 & 16 & 33 & 12 \\
\hline
\end{tabular}

Associates`skills- are evaluated as average value of eight factors: team members are appropriately trained and competent for professional work performance; team members are appropriately trained in administrative work and procedures connected to work; there is a formal system for recognizing needs for professional development and additional education of employees; needs for education and development are identified as a part of system; on the basis of analyzed employees' needs, additional training is given; team members are flexible and willing to perform also other tasks within the team; team members highly value additional education. In table 2 are given average value, standard deviation and coefficient of variation for particular factors of associates`skills.

Innovations are evaluated as average value of eight factors: team members are encouraged to try new work methods, team is included from the very beginning in new projects connected to its products/services, every innovation in team work is appreciated and rewarded, problems connected to business/clients are discovered quickly, the discovered problems are solved quickly, problem solving is seen as learning and development of the team, team members often suggest innovations in work and finally, team members readily accept innovations. In table 3 are given average value, standard deviation and coefficient of variation for particular factors of innovations in team.

Quality is estimated as average value of eight factors: team members are familiar with their clients` needs, it is clearly defined who are the clients of specific team, standards of work within the team are clearly defined, standards of work are followed regularly, feedback information on monitoring team work is received regularly, quantative standards of effectiveness are followed, team observes organizational standards for solving clients` complaints and complaints are considered regularly, and lessons are applied in further work. In table 4 are given average value, standard deviation and coefficient of variation for particular factors of team quality. On the basis of these tables, table 5 is formed which shows average value of team work and interpersonal relationships.

From table 5 we can see that average value of team work and interpersonal relationships in small and middle-sized enterprises amount to 3.31. The highest average value has synergy of team (3.51) which indicates that in these companies great attention is paid to developing the sense of belonging shared by all members of the team. Innovations have the 
lowest average value (3.21) which shows that they are neglected in a way.

Table 2: Assessment of associates`skills $(N=78)$

\begin{tabular}{|l|c|c|c|c|c|c|c|c|}
\hline & $\begin{array}{c}\text { Average } \\
\text { value }\end{array}$ & $\begin{array}{c}\text { Standard } \\
\text { deviation }\end{array}$ & $\begin{array}{c}\text { Coefficient of } \\
\text { variation }(\%)\end{array}$ & 1 & 2 & 3 & 4 & 5 \\
\hline $\begin{array}{l}\text { Training and competence for professional } \\
\text { work performance }\end{array}$ & 3.42 & 1.05 & 30.70 & 2 & 17 & 15 & 34 & 10 \\
\hline $\begin{array}{l}\text { Training in administrative work and } \\
\text { procedures }\end{array}$ & 3.38 & 1.03 & 30.57 & 3 & 14 & 20 & 32 & 9 \\
\hline $\begin{array}{l}\text { Formal system for recognizing needs for } \\
\text { education }\end{array}$ & 3.11 & 0.99 & 31.88 & 5 & 15 & 28 & 26 & 4 \\
\hline Systematic identifying of need for education & 2.91 & 1.02 & 35.10 & 5 & 25 & 24 & 20 & 4 \\
\hline $\begin{array}{l}\text { Additional training is given on the basis of } \\
\text { employees`needs }\end{array}$ & 2.79 & 1.07 & 38.41 & 8 & 26 & 22 & 18 & 4 \\
\hline $\begin{array}{l}\text { Competence of team members for different } \\
\text { tasks within the team }\end{array}$ & 3.53 & 1.02 & 28.81 & 3 & 11 & 16 & 38 & 10 \\
\hline $\begin{array}{l}\text { Willingness of team members to perform } \\
\text { other tasks within the team }\end{array}$ & 3.56 & 0.99 & 27.72 & 2 & 11 & 17 & 37 & 11 \\
\hline $\begin{array}{l}\text { Team members highly value additional } \\
\text { education }\end{array}$ & 3.49 & 0.95 & 27.24 & 1 & 11 & 26 & 29 & 11 \\
\hline
\end{tabular}

Table 3: Assessment of innovations in team $(N=78)$

\begin{tabular}{|l|c|c|c|c|c|c|c|c|}
\hline & $\begin{array}{c}\text { Average } \\
\text { value }\end{array}$ & $\begin{array}{c}\text { Standard } \\
\text { deviation }\end{array}$ & $\begin{array}{c}\text { Coefficient of } \\
\text { variation(\%) }\end{array}$ & 1 & 2 & 3 & 4 & 5 \\
\hline $\begin{array}{l}\text { Encouragement of team members to } \\
\text { try new work methods }\end{array}$ & 3.32 & 0.99 & 29.72 & 3 & 12 & 28 & 27 & 8 \\
\hline $\begin{array}{l}\text { Team is included from the beginning } \\
\text { in new projects }\end{array}$ & 3.31 & 1.01 & 30.55 & 4 & 12 & 25 & 30 & 7 \\
\hline $\begin{array}{l}\text { Every innovation in team work is appreciated } \\
\text { and rewarded }\end{array}$ & 2.74 & 1.10 & 40.03 & 11 & 22 & 25 & 16 & 4 \\
\hline $\begin{array}{l}\text { Problems connected to business/clients } \\
\text { are discovered quickly }\end{array}$ & 3.35 & 1.04 & 31.15 & 4 & 13 & 21 & 32 & 8 \\
\hline $\begin{array}{l}\text { Discovered problems are solved } \\
\text { quickly }\end{array}$ & 3.22 & 1.03 & 31.93 & 5 & 12 & 29 & 25 & 7 \\
\hline $\begin{array}{l}\text { Problem solving is seen as learning } \\
\text { and development of the team }\end{array}$ & 3.41 & 0.96 & 28.13 & 3 & 9 & 27 & 31 & 8 \\
\hline $\begin{array}{l}\text { Team members often suggest } \\
\text { innovations }\end{array}$ & 3.04 & 1.01 & 33.31 & 1 & 28 & 23 & 19 & 7 \\
\hline $\begin{array}{l}\text { Team members readily accept } \\
\text { innovations }\end{array}$ & 3.27 & 0.93 & 28.61 & 1 & 15 & 32 & 22 & 8 \\
\hline
\end{tabular}

Table 4: Assessment of team quality $(N=78)$

\begin{tabular}{|l|c|c|c|c|c|c|c|c|}
\hline & $\begin{array}{c}\text { Average } \\
\text { value }\end{array}$ & $\begin{array}{c}\text { Standard } \\
\text { deviation }\end{array}$ & $\begin{array}{c}\text { Coefficient of } \\
\text { variation(\%) }\end{array}$ & 1 & 2 & 3 & 4 & 5 \\
\hline $\begin{array}{l}\text { Team members are familiar with their } \\
\text { clients`needs }\end{array}$ & 3.47 & 0.94 & 26.94 & 2 & 10 & 23 & 35 & 8 \\
\hline $\begin{array}{l}\text { It is clearly defined who are the team`s } \\
\text { clients }\end{array}$ & 3.49 & 0.99 & 28.39 & 3 & 11 & 17 & 39 & 8 \\
\hline $\begin{array}{l}\text { Standards of work within the team are } \\
\text { clearly defined }\end{array}$ & 3.22 & 1.03 & 31.93 & 5 & 12 & 29 & 25 & 7 \\
\hline $\begin{array}{l}\text { Standards of work are followed } \\
\text { regularly }\end{array}$ & 3.17 & 1.02 & 32.35 & 3 & 19 & 25 & 24 & 7 \\
\hline $\begin{array}{l}\text { Feedback on monitoring team work is } \\
\text { received regularly }\end{array}$ & 3.05 & 1.04 & 34.19 & 5 & 19 & 27 & 21 & 6 \\
\hline $\begin{array}{l}\text { Quantative standards of effectiveness } \\
\text { are followed }\end{array}$ & 3.05 & 1.04 & 34.19 & 6 & 16 & 30 & 20 & 6 \\
\hline $\begin{array}{l}\text { Team observes organizational standards } \\
\text { for solving clients complaints }\end{array}$ & 3.28 & 0.98 & 29.83 & 4 & 10 & 31 & 26 & 7 \\
\hline $\begin{array}{l}\text { Complaints are considered regularly, } \\
\text { and lessons are applied in further work }\end{array}$ & 3.31 & 1.01 & 30.55 & 4 & 12 & 25 & 30 & 7 \\
\hline
\end{tabular}


Table 5: Average value of team work and interpersonal relationships

\begin{tabular}{|l|c|c|c|c|c|}
\hline & Synergy & Skills & Inovations & Quality & Average value \\
\hline Small and middle-sized enterprises (N=78) & 3.51 & 3.27 & 3.21 & 3.25 & 3.31 \\
\hline
\end{tabular}

\section{CONCLUSION}

Team effectiveness can be measured by individual and group results that are a product of forming inner processes in groups leading to a result. These processes are normally under influence of managers who form teams, while in-group processes present one of the most influential determinants of higher team effectiveness. They include orientation to common goal, cohesiveness, communication, decision making, work tasks and conflict resolution. In other words, effectiveness of team work is based on the end result of work, but also on satisfaction of team members. The end result is determined by qualitative and quantitative achievements of the team defined through team goals, while satisfaction is based on possibility of team work to satisfy basic needs of members and in this way increase loyalty to team, i.e. company. In order for companies to hold and maintain their competitive advantage on the market they have to pay great attention to fostering team work. Managers play an important role in this. They have to pick out individuals who have interpersonal skills for team work, to enable their training so they can develop skills of team work and to reward them appropriately for common efforts.

\section{REFERENCES}

Bateman, B., Wilson C.F., \& Bingham, D. (2002). Team effectiveness - development of an audit questionnaire. Journal of Management Developement, 21(3).

Janićijević, N. (2008). Organizational behaviour (in Serbian). Belgrade, RS: Data Status.

Lekić, S. (2010) The influence of organizational behaviour on organizational dedication (doctoral thesis). Novi Pazar, RS: Faculty for management and business economics, International university.

Pavlovski, T., \& Pavlović - Breneselović, D. (2000). Team work in pegagogical practice (in Serbian). Belgrade, RS: Faculty of Philosophy - Institute for pedagogy and adult education.

Robbins, S., \& Coulter, M. (2005). Management (in Serbian). Belgrade, RS: Data Status.

Robbins, S.P., \& Judge, T.A. (2010). Organizational behaviour (in Croatian). Zagreb, HR: Mate.

Zemke, R. (November 1993). Rethiking the Rush to Team Up. Training. 